\title{
Fundusze pożyczkowe i poręczeniowe a małe i średnie przedsiębiorstwa - wzajemne interakcje
}

\author{
ROBERT WOLAŃSKI \\ dr hab., Uniwersytet Warszawski, Wydział Zarządzania \\ rwolanski@wz.uw.edu.pl
}

SŁoWA KLuczowe MŚP, pożyczka, poręczenie, fundusz

ABSTRAKT Przedmiotem artykułu są powiązania funduszy poręczeniowych i pożyczkowych z mikro-, małymi i średnimi przedsiębiorstwami (MŚP). Celem opracowania jest określenie wzajemnych relacji tych dwóch grup podmiotów, wynikających z zakresu współpracy, postawy i działań.

Do realizacji celu, jako metody badawcze, wykorzystano analizę:

- dostępnej literatury, w tym badań innych autorów,

- danych statystycznych,

- MŚP dotyczącą powiązań MŚP z funduszami poręczeniowymi i pożyczkowymi,

- funduszy pożyczkowych i poręczeniowych dotyczącą ich postawy wobec MŚP,

- oferty funduszy pożyczkowych i poręczeniowych.

Za wynik tej analizy należy przyjąć potwierdzenie następujących tez:

- ogół MŚP w niewielkiej skali wykorzystuje narzędzia finansowe, jakimi są poręczenia i pożyczki, natomiast formy te mają duże znaczenie dla mikro- i małych przedsiębiorstw, które zdecydowały się z nich korzystać,

- dobre dopasowanie oferty funduszy do specyfiki MŚP, przejawiające się uwzględnieniem ich cech,

- bierna postawa MŚP wobec pozyskania środków z funduszy, wynikająca przede wszystkim z braku wiedzy.

W artykule wykorzystano jako podstawowe narzędzie analizy różne metody badawcze oraz źródła badawcze w celu określenia relacji funduszy pożyczkowych i poręczeniowych z sektorem MŚP.

\section{Loan and Guarantee Funds in Relation to Micro, Small and Medium-Sized Enterprises - Interactions \\ KEYWORDS \\ SMEs, loan, guarantee, fund}

ABSTRACT
The article discusses the problem of the link between guarantee and loan funds with micro, small and medium-sized enterprises (SMEs). The purpose of this article is to determine the relationship of these two groups of entities to each other, resulting from the scope of cooperation, attitude, action.

To realize the purpose of article, as a research method, used the analysis of available literature, including studies by other authors, statistical data, SME survey of SMEs connection with guarantee and loan funds, survey of loan and guarantee funds for their attitudes towards SMEs, study the offer of loan and guarantee funds.

As the result of the article is the verification of following thesis:

- small scale use of guarantees and loans by all SMEs, but their high importance for micro and small enterprises, which use from these forms,

- funds offer a good fit to the specificity of SMEs, manifested in regard to their characteristics, 
- passive attitude of SMEs to obtain funds, resulting primarily from a lack of knowledge.

The originality of the article manifests itself in the use of various research methods, from various sources, to determine the mutual relationship of loan and guarantee funds with the SME sector.

\section{Wprowadzenie}

Współdziałanie banków z MŚP w zakresie udzielania kredytów wskazuje na wiele ograniczeń i trudności w dostępie małych i średnich przedsiębiorstw do tego źródła finansowania (Bławat, 2004; Nogalski, Karpacz, Wójcik-Karpacz, 2004; Poznańska, 1998). W konsekwencji pojawia się przestrzeń, którą zagospodarowują organizacje pozabankowe, które decydują się na finansowanie MŚP, przyczyniając się do zmniejszenia luki finansowej w tym sektorze (Bernat, 2015). Wśród tych organizacji występują fundusze pożyczkowe, bezpośrednio udzielając im wsparcia finansowego oraz fundusze poręczeniowe, które poręczając kredyt lub pożyczkę, w konsekwencji umożliwiają ich zaciągnięcie. Oferta tych funduszy jest skierowana bezpośrednio do niewielkich przedsiębiorstw, stąd relacje między nimi należy uznać za kluczowe dla lepszego dopasowania do siebie podmiotów z obu tych sektorów. Badaniu poddano relacje między nimi, uwzględniając następujące aspekty:

- liczbę i wartość udzielonych poręczeń i pożyczek jako wyznacznik znaczenia funduszy poręczeniowych i pożyczkowych dla MŚP,

- badanie uzyskanych efektów wykorzystania pożyczek i poręczeń przez MŚP jako wyznacznika znaczenia funduszy poręczeniowych i pożyczkowych dla tych firm,

- dopasowanie do specyfiki MŚP oferty funduszy poręczeniowych i pożyczkowych,

- postawę wobec siebie obu grup podmiotów.

Badanie relacji między funduszami a MŚP przeprowadzono na podstawie następujących źródeł:

- analizy dostępnej literatury, w tym badań innych autorów, poświęconej powiązaniom MŚP z funduszami pożyczkowymi i poręczeniowymi,

- badania danych statystycznych dotyczących stopnia korzystania MŚP z pożyczek i poręczeń, oferowanych przez fundusze pożyczkowe i poręczeniowe,

- badania dotyczącego powiązań MŚP z funduszami poręczeniowymi i pożyczkowymi (przeprowadzonego przez autora artykułu),

- badania funduszy pożyczkowych i poręczeniowych dotyczących ich postawy wobec MŚP (przeprowadzonego przez autora artykułu),

- badania oferty funduszy pożyczkowych i poręczeniowych (przeprowadzonego przez autora artykułu).

Badanie własne autora artykułu było realizowane techniką wywiadów bezpośrednich w MŚP, wspomaganych komputerowo (CAPI). Realizowane było na próbie 223 przedsiębiorstw, wśród których 99 to mikroprzedsiębiorstwa, 70 podmiotów - małe przedsiębiorstwa i 54 podmioty - średnie przedsiębiorstwa. Ze względu na lokalizację działalności i sektor działalności, badanie należy uznać za reprezentatywne. $Z$ uwagi na liczbę respondentów i rozmiar terenu objęty analizą, zebranie ankiet zlecono firmie badawczej. Ankiety zebrano w okresie od 10 maja do 10 czerwca 2010 roku. Ze względu na to, że struktura próby nie odzwierciedlała struktury populacji pod względem wielkości przedsiębiorstwa, aby umożliwić prezentację wyników i nadać próbie charakter reprezentatywny, zastosowano procedurę ważenia wyników. 
W odniesieniu do funduszy pożyczkowych i poręczeniowych tematem badania była ich opinia w stosunku do MŚP oraz własnej postawy wobec tych przedsiębiorstw. W ankiecie pytano m.in. o działania podjęte celem dostosowania oferty do sektora MŚP, jak również o mocne i słabe strony współpracy. Przedmiotem badania była ocena wzajemnych relacji między sektorem MŚP a funduszami. Badanie realizowano techniką wywiadów telefonicznych wspomaganych komputerowo (CATI). Czas trwania wywiadu wynosił około 10 minut. Wywiady zrealizowano w okresie od czerwca do września 2010 roku.

Badaniem objęto również ofertę funduszy, czyli rzeczywiste warunki uzyskania poręczeń lub pożyczek przez MŚP, na dzień 1 września 2016 roku. Analizie poddano 20 ofert funduszy poręczeniowych oraz 20 funduszy pożyczkowych, przyjmując za kryterium wielkość funduszu liczoną wysokością kapitału.

\section{Fundusze pożyczkowe i poręczeniowe - pojęcie i funkcje}

Instytucja funduszy pożyczkowych i poręczeniowych w literaturze przedmiotu jest najczęściej definiowana jako (Janc i Waliszewski 2014):

- instytucje mikrofinansowe umożliwiające pozyskanie niewielkiego wsparcia finansowego, głównie mikroprzedsiębiorcom rozpoczynającym lub prowadzącym działalność gospodarczą na niewielką skalę (Bartkowiak i in., 2006; Alińska, 2008),

- parabanki udzielające pożyczek firmom z sektora MŚP lub umożliwiające dostęp do pożyczek i kredytów na rynku finansowym,

- instytucje otoczenia biznesu o charakterze niekomercyjnym, będące w orbicie zainteresowań najmniejszych podmiotów gospodarczych.

Powyższe definicje wskazują na istotną funkcję funduszy, jaką jest poprawa dostępu do zewnętrznych źródeł finansowania przez możliwość uzyskania pożyczki lub skorzystania z poręczenia firm z sektora MŚP. Drugoplanową funkcją jest pobudzanie przedsiębiorczości poprzez doradztwo oraz tworzenie historii kredytowej (Mikołajczyk, 2007).

\section{Stopień korzystania z funduszy pożyczkowych i poręczeniowych przez małe i średnie przedsiębiorstwa}

Znaczenie i efekty działalności funduszy lokalnych i regionalnych oraz ich aktywność obrazują dane na temat wartości kapitału funduszy oraz liczba i wartości udzielonych poręczeń. Dane na ten temat za lata 1994-2015 przedstawiono w tabeli 1.

Tabela 1. Wyniki działalności funduszy poręczeniowych w latach 1994-2015

\begin{tabular}{|c|c|c|c|c|c|c|c|c|c|c|}
\hline & $1994-1998$ & 1999 & 2000 & 2001 & 2002 & 2003 & 2004 & 2005 & 2006 & 2007 \\
\hline LF & b.d. & 17 & 17 & 24 & 39 & 50 & 61 & 54 & 53 & 51 \\
\hline & \multicolumn{10}{|c|}{ Wartość kapitałów funduszy (mln zł) i dynamika (\%) } \\
\hline W & b.d. & 30,6 & 37,1 & 35,9 & 92,9 & 133,9 & 186,7 & 288,4 & 443,0 & 588,6 \\
\hline D & b.d. & b.d. & 21,2 & $-3,2$ & 158,8 & 44,1 & 39,4 & 54,5 & 53,6 & 32,9 \\
\hline & \multicolumn{10}{|c|}{ Liczba udzielonych poręczeń i dynamika (\%) } \\
\hline L & 989 & 434 & 425 & 415 & 810 & 1,534 & 2,212 & 3,101 & 4,611 & 5,312 \\
\hline
\end{tabular}




\begin{tabular}{|c|c|c|c|c|c|c|c|c|c|c|}
\hline & $1994-1998$ & 1999 & 2000 & 2001 & 2002 & 2003 & 2004 & 2005 & 2006 & 2007 \\
\hline D & b.d. & b.d. & $-2,1$ & $-2,4$ & 95,2 & 89,4 & 44,2 & 40,2 & 48,7 & 15,2 \\
\hline & \multicolumn{8}{|c|}{ Wartość udzielonych poręczeń (mln zł) i dynamika (\%) } \\
\hline W & 48,1 & 26,6 & 23,4 & 23,1 & 47,6 & 85,6 & 132,8 & 221,8 & 401,5 & 599,9 \\
\hline D & b.d. & b.d. & $-12,0$ & $-1,3$ & 106,1 & 79,8 & 55,1 & 67,0 & 81,0 & 49,4 \\
\hline & 2008 & 2009 & 2010 & 2011 & 2012 & 2013 & 2014 & 2015 & Suma & \\
\hline LF & 49 & 45 & 47 & 51 & 49 & 48 & 45 & 44 & - \\
\hline \multicolumn{8}{|c|}{ Wartość kapitałów funduszy (mln zł) i dynamika (\%) } \\
\hline W & 605,7 & 701,3 & 992,2 & 1035,4 & 1104,7 & 1222,6 & 1171,8 & 1127,0 & - \\
\hline D & 2,9 & 15,8 & 41,5 & 4,4 & 6,7 & 10,7 & $-4,2$ & $-3,8$ & - \\
\hline \multicolumn{8}{|c|}{ Liczba udzielonych poręczeń i dynamika (\%) } \\
\hline L & 5,684 & 6,568 & 7,144 & 6,118 & 5,678 & 6,175 & 5,578 & 6,336 & 69,124 \\
\hline D & 7,0 & 15,5 & 8,8 & $-14,4$ & $-7,2$ & 8,8 & $-9,7$ & 13,6 & - \\
\hline & \multicolumn{8}{|c|}{ Wartość udzielonych poręczeń (mln zł) i dynamika (\%) } \\
\hline W & 745,3 & 793,4 & 869,2 & 967,0 & 1190,0 & 876,7 & 833,3 & 923,8 & 8809,1 \\
\hline D & 24,2 & 6,5 & 9,6 & 11,3 & 23,1 & $-26,3$ & $-5,0$ & 10,9 & - \\
\hline
\end{tabular}

b.d. - brak danych, LF - liczba funduszy, L - liczba, W - wartość, D - dynamika.

Źródło: opracowanie własne na podstawie Raporty o stanie funduszy... (2002-2016).

Zaprezentowane powyżej dane ukazują znaczny rozwój działalności funduszy lokalnych i regionalnych, szczególnie od 2002 roku. Należy przede wszystkim zwrócić uwagę na przyrost kapitałów, głównie w latach 2002-2013. Ich wysokość faktycznie określa, jaka wartość poręczeń mogła być udzielona. Analizowanemu przyrostowi towarzyszy wzrost znaczenia funduszy na rynku, co obrazuje liczba i wartość udzielonych poręczeń. Należy podkreślić, że od 1994 roku fundusze przyznały 69124 poręczeń na kwotę 8809,1 mln zł. Oznacza to systematyczny i wysoki wzrost liczby i wartości udzielanych poręczeń od 2002 roku poza nielicznymi wyjątkami.

Fundusze poręczeniowe pośrednio umożliwiają MŚP dostęp do kapitałów. W sposób bezpośredni robią to fundusze pożyczkowe, które dostarczają sektorowi mikro-, małych i średnich przedsiębiorstw potrzebnych środków na bieżącą działalność i inwestycje. Wyniki działalności funduszy pożyczkowych przedstawiono w tabeli 2 .

Tabela 2. Wyniki działalności funduszy pożyczkowych za lata 1994-2015

\begin{tabular}{|l|c|c|c|c|c|c|c|c|}
\hline & $1994-2002$ & 2003 & 2004 & 2005 & 2006 & 2007 & 2008 & 2009 \\
\hline Liczba funduszy & b.d. & 76 & 77 & 81 & 75 & 73 & 71 & 70 \\
\hline $\begin{array}{l}\text { Wartość kapitału funduszy } \\
\text { (mln zł) }\end{array}$ & b.d. & 368,3 & 437,8 & 558,2 & 712,5 & 823,2 & 946,4 & 960,8 \\
\hline Dynamika wartości kapitału (\%) & b.d. & b.d. & 18,9 & 27,5 & 27,6 & 15,3 & 15,0 & 1,5 \\
\hline $\begin{array}{l}\text { Liczba udzielonych pożyczek } \\
\text { (tys.) }\end{array}$ & 71,4 & 11,5 & 13,3 & 16,0 & 19,5 & 21,0 & 19,6 & 16,7 \\
\hline $\begin{array}{l}\text { Dynamika udzielonych pożyczek } \\
(\%)\end{array}$ & b.d. & b.d. & 15,7 & 20,3 & 21,9 & 7,7 & $-6,7$ & $-14,8$ \\
\hline
\end{tabular}

1 Duży wpływ na dane za 2009 r. i od 2010 r. ma zaprzestanie działalności pożyczkowej w drugiej połowie 2009 r. przez Fundusz Mikro, jeden z największych podmiotów na rynku funduszy pożyczkowych. Jego znaczenie związane jest $\mathrm{z}$ faktem, że udzielał on około $70 \%$ wszystkich pożyczek o wartości stanowiącej około $33 \%$ ogółu wartości pożyczek. Według danych na 31.12.2009 r. udzielił 130,65 tys. pożyczek z łącznej liczby 188 tys. pożyczek. 


\begin{tabular}{|l|c|c|c|c|c|c|c|c|}
\hline & $1994-2002$ & 2003 & 2004 & 2005 & 2006 & 2007 & 2008 & 2009 \\
\hline $\begin{array}{l}\text { Wartość udzielonych pożyczek } \\
\text { (mln zł) }\end{array}$ & 992,7 & 174,0 & 204,4 & 240,8 & 370,6 & 417,5 & 438,4 & 333,1 \\
\hline Dynamika wartości (\%) & b.d. & b.d. & 17,5 & 17,8 & 53,9 & 12,7 & 5,0 & $-24,0$ \\
\hline Liczba funduszy & 2010 & 2011 & 2012 & 2013 & 2014 & 2015 & Suma & - \\
\hline $\begin{array}{l}\text { Wartość kapitału funduszy (mln } \\
\text { zł) }\end{array}$ & 70 & 66 & 63 & 65 & 72 & 71 & - & - \\
\hline Dynamika wartości kapitału (\%) & 68,1 & 2,0 & 20,4 & 9,3 & 17,1 & 6,6 & - \\
\hline $\begin{array}{l}\text { Liczba udzielonych pożyczek } \\
\text { (tys.) }\end{array}$ & 7,6 & 8,7 & 8,3 & 8,1 & 8,6 & 8,8 & 238,1 \\
\hline $\begin{array}{l}\text { Dynamika udzielonych pożyczek } \\
\text { (\%) }\end{array}$ & $-54,5$ & 14,5 & $-4,6$ & $-2,4$ & 6,2 & 2,3 & - \\
\hline $\begin{array}{l}\text { Wartość udzielonych pożyczek } \\
\text { (mln zł) }\end{array}$ & 424,3 & 569,8 & 639,1 & 767,5 & 893,8 & 878,8 & 7323,1 \\
\hline Dynamika wartości (\%) & 27,4 & 34,3 & 12,2 & 20,1 & 16,5 & $-1,7$ & - \\
\hline
\end{tabular}

b.d. - brak danych.

Źródło: opracowanie własne na podstawie raportów: Fundusze pożyczkowe... (2005-2009); Stan i perspektywy rozwoju... (2011); Rynek funduszy pożyczkowych... (2012-2016).

Działalność funduszy pożyczkowych, podobnie jak poręczeniowych, wykazuje tendencję wzrostową. Przede wszystkim rośnie kapitał funduszy, który może być wykorzystany na pożyczki, wzrasta również wartość udzielonych pożyczek. W latach 2003-2015 kapitał tych instytucji finansowych wzrósł ponad siedmiokrotnie, a wartość pożyczek pięciokrotnie. Z kolei liczba udzielonych pożyczek od 2010 roku utrzymuje się na zbliżonym poziomie.

Przyjmując za podstawę liczbę aktywnie działających MŚP w 2013 roku, która wynosiła 1768242 przedsiębiorstw, okazuje się, że w latach 1995-2015 17,4\% najmniejszych podmiotów skorzystało z usług funduszy pożyczkowych i poręczeniowych, z czego 3,9\% MŚP uzyskało poręczenie, a 13,5\% MŚP zaciągnęło pożyczki. Wynika z tego, że średniorocznie tylko około 0,83\% MŚP korzysta z poręczeń i pożyczek. W 2015 roku natomiast przyznano 6336 poręczeń i 8800 pożyczek, co oznacza, że skorzystało z nich $0,86 \%$ ogółu funkcjonujących mikro-, małych i średnich przedsiębiorstw. Pomimo wzrostów liczba i wartość udzielonych pożyczek i poręczeń jest nadal na niskim poziomie. Małe i średnie przedsiębiorstwa w niewielkim stopniu korzystają z oferty funduszy. Prezentowane zestawienie wskazuje, że przedsiębiorstwa przejawiają niewielkie zainteresowanie działalnością funduszy (Janc, Waliszewski 2014).

Przeprowadzone przez autora artykułu badanie miało wyjaśnić, dlaczego MŚP w tak niewielkim stopniu korzystają z usług funduszy. Główną przyczyną jest brak takiej potrzeby - na co wskazało 73,5\% MŚP w odniesieniu do funduszy poręczeniowych oraz 69,8\% MŚP w odniesieniu do funduszy pożyczkowych. Następną przyczyną przy funduszach poręczeniowych było to, że firma nie korzysta z pożyczek i kredytów (7,8\% MŚP), natomiast przy funduszach pożyczkowych wskazano na niechęć do korzystania z pożyczek (18,8\% MŚP). Powodem był również brak wiedzy na temat funduszy - 5,8\% MŚP zwróciło na to uwagę w odniesieniu do funduszy poręczeniowych i 7,3\% MŚP w odniesieniu do funduszy pożyczkowych. Należy zauważyć, że przedstawione powyżej przyczyny odpowiadają przyjętej w literaturze przedmiotu strukturze kapitałów w MŚP (Łuczka, 2001, 2013; Kubiak 2005). 


\section{Efekty wykorzystania pożyczek i poręczeń przez MŚP}

Badacze prowadzący analizy wykorzystania pożyczek i poręczeń przez MŚP uzyskali wyniki określające efekty wykorzystania tych środków. Głębszą analizę wykorzystania poręczeń podjęła w swoich badaniach B. Bartkowiak, której ocenę wpływu tych funduszy na funkcjonowanie i rozwój MŚP przedstawiono w tabeli 3.

Tabela 3. Wpływ funduszy poręczeniowych na funkcjonowanie i rozwój mikro-, małych i średnich przedsiębiorstw (\%)

\begin{tabular}{|l|c|c|c|c|c|c|}
\hline & $\begin{array}{c}\text { Nie } \\
\text { występuje }\end{array}$ & $\begin{array}{c}\text { Śladowy } \\
\text { wpływ }\end{array}$ & $\begin{array}{c}\text { Mały } \\
\text { wpływ }\end{array}$ & $\begin{array}{c}\text { Umiarkowany } \\
\text { wpływ }\end{array}$ & $\begin{array}{c}\text { Duży } \\
\text { wpływ }\end{array}$ & $\begin{array}{c}\text { Decydujący } \\
\text { wpływ }\end{array}$ \\
\hline $\begin{array}{l}\text { Przełamywanie barier w dostępie do } \\
\text { finansowania MŚP }\end{array}$ & 0,00 & 5,17 & 18,97 & 25,00 & 31,03 & 26,72 \\
\hline Wzmacnianie pozycji rynkowej MŚP & 0,00 & 6,90 & 11,21 & 25,86 & 34,48 & 29,31 \\
\hline $\begin{array}{l}\text { Uzyskanie kredytu bankowego bez } \\
\text { wystarczających zabezpieczeń }\end{array}$ & 1,72 & 2,72 & 12,07 & 18,97 & 35,34 & 26,72 \\
\hline $\begin{array}{l}\text { Wzmocnienie pozytywnej oceny } \\
\text { zdolności kredytowej przedsiębiorstwa } \\
\text { w ocenie banku }\end{array}$ & 0,86 & 3,45 & 7,76 & 30,17 & 38,79 & 20,69 \\
\hline $\begin{array}{l}\text { Aktywizowanie bezrobotnych i wsparcie } \\
\text { przy zakładaniu nowej działalności } \\
\text { gospodarczej }\end{array}$ & 6,03 & 6,90 & 17,24 & 28,45 & 28,45 & 17,24 \\
\hline $\begin{array}{l}\text { Możliwość finansowania inwestycji } \\
\text { przedsiębiorstw }\end{array}$ & 0,00 & 1,72 & 11,21 & 17,24 & 47,41 & 25,00 \\
\hline $\begin{array}{l}\text { Możliwość finansowania środków } \\
\text { obrotowych przedsiębiorstw }\end{array}$ & 0,86 & 1,72 & 8,62 & 27,59 & 38,79 & 25,86 \\
\hline $\begin{array}{l}\text { Możliwość finansowania w przypadku } \\
\text { podwyższonego/wysokiego ryzyka } \\
\text { przedsięwzięcia }\end{array}$ & 0,86 & 6,03 & 10,34 & 25,00 & 37,07 & 20,69 \\
\hline Inne & 0,86 & 0,86 & 2,59 & 10,34 & 6,90 & 6,90 \\
\hline
\end{tabular}

Źródło: Bartkowiak (2009), s. 205.

Biorąc pod uwagę wskazania respondentów, na duży i decydujący wpływ funduszy poręczeniowych na rozwój przedsiębiorstwa należy wyróżnić następujące czynniki:

- możliwość finansowania środków obrotowych przedsiębiorstw,

- możliwość finansowania inwestycji przedsiębiorstw,

- uzyskanie kredytu bankowego bez wystarczających zabezpieczeń,

- wzmocnienie pozytywnej oceny zdolności kredytowej przedsiębiorstwa w ocenie banku,

- wzmocnienie pozycji rynkowej MŚP.

Pierwsze cztery czynniki wynikają z samej istoty poręczeń, które służą pozyskaniu finansowania, głównie kredytu z banku. Na uwagę zasługuje ostatni czynnik, który pokazuje, że działalność funduszy poręczeniowych służy rozwojowi MŚP.

Z kolei z badań prowadzonych przez J. Adamka wynika, że w przypadku niemożności pozyskania poręczenia (Adamek 2006, s. 312):

- rozwój przedsiębiorstwa byłby ograniczony lub zahamowany - 76,3\% badanych przedsiębiorstw, 
- przedsiębiorstwo rozwijałoby się tak samo - 11,9\% badanych przedsiębiorstw,

- inny scenariusz - $8,5 \%$ badanych przedsiębiorstw,

- przedsiębiorstwo mogłoby upaść - 3,4\% badanych przedsiębiorstw.

Wyniki tego badania jednoznacznie wskazują na bezpośredni wpływ poręczeń na rozwój przedsiębiorstwa.

W badaniu B. Bartkowiak znajduje potwierdzenie również wyrażona przez respondentów ocena wpływu funduszy pożyczkowych na rozwój MŚP, co przedstawiono w tabeli 4.

Tabela 4. Wpływ funduszy pożyczkowych na funkcjonowanie i rozwój mikro-, małych i średnich przedsiębiorstw (\%)

\begin{tabular}{|l|c|c|c|c|c|c|}
\hline & $\begin{array}{c}\text { Nie } \\
\text { występuje }\end{array}$ & $\begin{array}{c}\text { Śladowy } \\
\text { wpływ }\end{array}$ & $\begin{array}{c}\text { Mały } \\
\text { wpływ }\end{array}$ & $\begin{array}{c}\text { Umiarkowany } \\
\text { wpływ }\end{array}$ & $\begin{array}{c}\text { Duży } \\
\text { wpływ }\end{array}$ & $\begin{array}{c}\text { Decydujący } \\
\text { wpływ }\end{array}$ \\
\hline $\begin{array}{l}\text { Przełamywanie barier w dostępie do } \\
\text { finansowania MŚP }\end{array}$ & 1,04 & 2,60 & 14,58 & 19,79 & 33,33 & 16,15 \\
\hline Wzmacnianie pozycji rynkowej MŚP & 0,00 & 3,13 & 7,81 & 25,52 & 31,77 & 20,83 \\
\hline $\begin{array}{l}\text { Kreowanie dobrej historii kredytowej } \\
\text { - stworzenie podwalin pod przysłą } \\
\text { współpracę z sektorem bankowym } \\
\text { poprzez mniejsze wymogi dotyczące } \\
\text { zabezpieczeń i zdolności kredytowej }\end{array}$ & 0,52 & 3,13 & 7,81 & 27,08 & 30,21 & 16,15 \\
\hline $\begin{array}{l}\text { Obniżenie kosztów finansowania } \\
\text { przedsiębiorcy }\end{array}$ & 1,04 & 5,21 & 14,06 & 22,92 & 29,69 & 12,50 \\
\hline $\begin{array}{l}\text { Aktywizowanie bezrobotnych } \\
\text { i wsparcie przy zakładaniu nowej } \\
\text { działalności gospodarczej }\end{array}$ & 3,13 & 5,73 & 8,33 & 20,31 & 33,33 & 14,06 \\
\hline $\begin{array}{l}\text { Mniej rygorystyczny i proceduralny } \\
\text { charakter funduszy pożyczkowych } \\
\text { w ocenie zdolności kredytowej } \\
\text { przedsiębiorcy oraz indywidualne } \\
\text { i elastyczne podejście do finansowania } \\
\text { przedsiębiorcy }\end{array}$ & 0,52 & 3,13 & 9,90 & 26,56 & 26,56 & 17,19 \\
\hline $\begin{array}{l}\text { Dostęp do informacji i doradztwa } \\
\text { o możliwych alternatywnych } \\
\text { wsparciach finansowych oraz szkolenia } \\
\text { w zakresie prowadzenia biznesu }\end{array}$ & 0,52 & 3,13 & 9,38 & 25,00 & 28,13 & 18,23 \\
\hline $\begin{array}{l}\text { Komplementarność w stosunku do } \\
\text { systemu bankowego i innych źródeł } \\
\text { zewnętrznego finansowania }\end{array}$ & 0,00 & 1,56 & 10,42 & 27,60 & 30,73 & 12,50 \\
\hline $\begin{array}{l}\text { Możliwość finansowania inwestycji } \\
\text { przedsiębiorstw }\end{array}$ & 0,00 & 2,08 & 3,13 & 18,23 & 38,02 & 21,35 \\
\hline $\begin{array}{l}\text { Możliwość finansowania w przypadku } \\
\text { podwyższonego/wysokiego ryzyka } \\
\text { przedsięwzięcia }\end{array}$ & 0,52 & 3,65 & 7,29 & 23,44 & 25,00 & 20,31 \\
\hline Inne & 0,52 & 0,52 & 1,56 & 6,77 & 8,33 & 2,08 \\
\hline
\end{tabular}

Źródło: Bartkowiak (2009), s. 202.

Biorąc pod uwagę wskazania respondentów, dotyczące dużego i decydującego wpływu funduszy pożyczkowych na rozwój przedsiębiorstwa, należy wyróżnić dwa czynniki: 
- możliwość finansowania inwestycji przedsiębiorstw,

- wzmacnianie pozycji rynkowej MŚP.

Analizowane MŚP podkreślają rolę poręczeń i pożyczek we wzmacnianiu pozycji rynkowej. Oznacza to, że MŚP traktują tę formę finansowania jako czynnik wpływający na ich rozwój.

\section{Dopasowanie oferty funduszy poręczeniowych i pożyczkowych do specyfiki MŚP}

Zgodnie z badaniami MŚP przeprowadzonymi przez autora artykułu, najważniejszą cechą funduszy poręczeniowych, która wpływa na zainteresowanie nimi przez MŚP, jest wykorzystanie do poręczenia kredytu bankowego. Na tę formę finansowania wskazało 93\% MŚP, które zamierzały zaciągnąc kredyt bankowy. Pozostałe czynniki miały niewielkie znaczenie przy wyborze poręczeń przez MŚP. W odniesieniu do funduszy pożyczkowych najistotniejszą cechą, która decydowała o wyborze tego produktu, było dobre dopasowanie do specyfiki MŚP. Została podkreślona prostota przyznawania środków (45\% MŚP), indywidualne podejście do przedsiębiorstwa (29\% MŚP) oraz prosta procedura przyznawania środków (28\% MŚP).

W tym badaniu MŚP porównano jednocześnie ofertę kredytową banków (kredyt bankowy jest najczęściej wykorzystywanym instrumentem finansowania zewnętrznego przez MŚP) z ofertą funduszy pożyczkowych i poręczeniowych oferujących produkty o zbliżonej charakterystyce, które były kierowane głównie do MŚP. Oferta tych funduszy wyraźnie różni się na ich korzyść, w stosunku do oferty bankowej (tab. 5). Preferencyjne traktowanie MŚP przez fundusze pożyczkowe przejawia się przede wszystkim w niższym koszcie pożyczek, prostszej ich konstrukcji, uproszczeniu badania zdolności do spłaty pożyczki, uwzględnieniu specyfiki działania i cech pozafinansowych MŚP. Oznacza to, że oferta tych instytucji jest dużo bardziej atrakcyjna dla małych przedsiębiorców niż najpopularniejsza oferta kredytowa banków.

Tabela 5. Zestawienie głównych różnic oferty funduszy pożyczkowych i funduszy poręczeniowych w stosunku do oferty kredytowej banków

\begin{tabular}{|l|c|c|c|c|}
\hline & Fundusze pożyczkowe i poręczeniowe & \multicolumn{2}{|c|}{ Banki } \\
\cline { 2 - 5 } & $\mathrm{n}$ & $\%$ & $\mathrm{n}$ & $\%$ \\
\hline Preferencyjne traktowanie MŚP & 4 & 80 & 2 & 33 \\
\hline Niższe koszty pożyczek & 5 & 100 & 3 & 50 \\
\hline Prostsza konstrukcja pożyczek & 4 & 80 & 2 & 33 \\
\hline Uproszczone metody badania zdolności do spłaty pożyczki & 4 & 80 & 2 & 33 \\
\hline Stosowanie prostszych form zabezpieczeń spłaty pożyczki & 3 & 60 & 2 & 33 \\
\hline $\begin{array}{l}\text { Uwzględnianie specyfiki działania MŚP przy ustalaniu } \\
\text { warunków udzielenia pożyczki }\end{array}$ & 4 & 80 & 1 & 17 \\
\hline Zwracanie dużej uwagi na cechy pozafinansowe MŚP & 5 & 100 & 1 & 17 \\
\hline
\end{tabular}

$\mathrm{n}$ - liczba pozytywnych odpowiedzi wraz z ich udziałem w badanej próbie.

Źródło: opracowanie własne. 
W badaniu B. Bartkowiak, podmioty korzystające z poręczeń wskazywały na następujące trudności przy aplikowaniu o uzyskanie poręczenia (Bartkowiak, 2009, s. 206):

- skomplikowane procedury - 30,2\% odpowiedzi,

- brak wyczerpujących informacji o zasadach korzystania z poręczenia kredytowego - $26,4 \%$ odpowiedzi,

- zbyt wysoki koszt - 24,5\% odpowiedzi,

- brak wystarczającego doradztwa i mało przychylny klimat - 5,7\% odpowiedzi,

- inne - $13,2 \%$ odpowiedzi.

Z przedstawionych badań wynika, że bariery korzystania przez MŚP z oferty funduszy poręczeniowych związane są ze stosowanymi przez nie warunkami udzielenia poręczenia.

W tym samym badaniu, wśród badanych przedsiębiorstw $12 \%$ podmiotów korzystało z pożyczek. Wśród nich $85 \%$ nie napotkało żadnych trudności w trakcie aplikowania i korzystania z pożyczki z funduszu pożyczkowego (Bartkowiak, 2009, s. 202). Prezentowany wysoki odsetek MŚP, wskazuje na wyjątkowo dobre dopasowanie oferty i warunków przyznawania pożyczek do specyfiki MŚP. Z kolei pozostałe 15\% przedsiębiorstw, które napotkały trudności, wskazały na następujące trudności przy aplikowaniu o uzyskanie pożyczki (Bartkowiak, 2009, s. 206):

- brak wyczerpujących informacji o zasadach korzystania z pożyczki - 40,9\% odpowiedzi,

- zbyt wysoki koszt - 22,7\% odpowiedzi,

- skomplikowane procedury - 13,6\% odpowiedzi,

- brak wystarczającego doradztwa i mało przychylny klimat - 13,6\% odpowiedzi,

- inne - 9,1\% odpowiedzi.

Mając powyższe na uwadze, istotną kwestią analizy jest ocena oferty funduszy poręczeniowych i funduszy pożyczkowych kierowanych do MŚP. Temu zagadnieniu poświęcone jest przeprowadzone przez autora artykułu badanie.

W przypadku funduszy poręczeniowych za główne utrudnienie w relacjach z MŚP należy uznać procedurę udzielania poręczenia w zakresie wymaganych dokumentów, sposobu weryfikacji klienta, długości oczekiwania na decyzję. Aktualnie funkcjonujące rozwiązania są zbyt skomplikowane i stanowią duże obciążenie dla MŚP. Wydają się zatem niepotrzebne, biorąc pod uwagę wcześniejszą analizę przeprowadzoną przez bank, a także ograniczenie działalności funduszu do lokalnych MŚP. Należy także wspomnieć o krótkim okresie obowiązywania poręczenia.

Z kolei wśród rozwiązań wychodzących naprzeciw MŚP należy wymienić możliwość poręczenia wszystkich kredytów gospodarczych, stosunkowo niski koszt poręczenia, ograniczenie działalności w stosunku do MŚP z danego regionu, stosowanie prostych rodzajów zabezpieczeń poręczenia oraz elektronicznie dostępną ofertę funduszu i potrzebne wzory dokumentów. Rozwiązania te stwarzają możliwość dostępu poręczeń dla dużej liczby MŚP, przyczyniając się jednocześnie do ich rozwoju.

Podobnie dla dokładnego określenia relacji pomiędzy funduszami pożyczkowymi a sektorem MŚP przeprowadzono badanie oferty tych funduszy. Na podstawie tego badania można przedstawić następujące cechy charakteryzujące ofertę funduszy pożyczkowych.

Należy podkreślić dostępność funduszy pożyczkowych dla wszystkich MŚP. Ma to szczególne znaczenie dla nowo powstałych podmiotów, opodatkowanych ryczałtowo, nieprowadzących 
ewidencji księgowej, dla których często jest to jedyne źródło pozyskania środków na działalność bieżącą czy rozwojową.

Fundusze wymagają przedstawienia wielu dokumentów, na podstawie których mozna wykazać zasadność finansowania pożyczką danych potrzeb przedsiębiorcy. Taka sytuacja wymaga od MŚP strategii prowadzonej działalności, to jest wskazania celu działalności, sposobu jej rozwoju i efektów. Wiele podmiotów, szczególnie najmniejszych i nowo założonych ma trudności ze stworzeniem wyżej wymienionej strategii, jak również sporządzeniem biznesplanu pokazującego sposób jej realizacji. Nie tylko umożliwiają im spełnienie warunków przy ubieganiu się o pożyczkę, ale służą pomocą przy zaplanowaniu rozwoju prowadzonej działalności, poprzez ofertę doradztwa w tym zakresie.

Za rozwiązanie właściwe wobec MŚP należy uznać wymagane przez fundusze sposoby zabezpieczenia spłaty pożyczki. W każdym funduszu głównym zabezpieczeniem jest weksel. Obok tej formy stosowane jest głównie poręczenie. Zabezpieczenia te należą do najprostszych, natomiast zastaw czy hipoteka dotyczą MŚP, które same mogą je wykorzystać.

Wśród rozwiązań niesprzyjających wykorzystaniu pożyczek przez najmniejsze podmioty jest ich wysokie oprocentowanie dla nowo założonych przedsiębiorstw. Ponadto, przy pożyczkach inwestycyjnych na wyższe kwoty, okres 5-letni może być za krótki, aby przedsiębiorstwo było zdolne finansowo ją obsłużyć.

Ofertę funduszy poręczeniowych i pożyczkowych należy uznać za dostosowaną do potrzeb i specyfiki MŚP. Biorąc pod uwagę, że z usług funduszy korzystają głównie mikro- i małe przedsiębiorstwa, istotną przesłanką jest pomoc oferowana przez fundusze odnośnie do wypełniania wymaganych dokumentów, w szczególności biznesplanu oraz wniosków poręczeniowych czy pożyczkowych. Wysokość poręczeń i pożyczek, okres umowy, wysokość oprocentowania, sposoby zabezpieczeń wychodzą naprzeciw małym podmiotom. Wśród rozwiązań utrudniających wzajemną współpracę można wymienić zbyt skomplikowaną procedurę udzielania poręczenia dotyczącą wymaganych dokumentów, sposobu weryfikacji klienta, długi czas oczekiwania na decyzję oraz gorsze traktowanie nowo założonych przedsiębiorstw przez fundusze pożyczkowe.

\section{Postawa funduszy poręczeniowych i pożyczkowych oraz MŚP wobec siebie}

Postawa funduszy poręczeniowych i pożyczkowych, ich postrzeganie MŚP było przedmiotem badań autora artykułu. Badanie zidentyfikowało działania podejmowane przez te instytucje w celu zwiększenia dostępności ich oferty dla małych i średnich przedsiębiorstw. Wśród najczęściej podawanych działań można wyróżnić:

- przeprowadzenie akcji informacyjnej o ofercie wśród MŚP (100\% funduszy pożyczkowych i poręczeniowych potwierdziło tę formę),

- zwracanie szerszej uwagi na cechy pozafinansowe MŚP oraz obniżenie kosztów oferowanych produktów (100\% funduszy pożyczkowych i 67\% funduszy poręczeniowych),

- uwzględnienie specyfiki MŚP przy ustalaniu warunków otrzymania produktu (100\% funduszy pożyczkowych i 50\% funduszy poręczeniowych),

- kompleksowa obsługa MŚP (80\% funduszy pożyczkowych i $83 \%$ funduszy poręczeniowych), 
- uproszczenie sposobu badania zdolności do spłat zobowiązania (80\% funduszy pożyczkowych i $50 \%$ funduszy poręczeniowych),

- stosowanie prostszych form zabezpieczeń (60\% funduszy pożyczkowych i $83 \%$ funduszy poręczeniowych).

Prezentowane badanie wykazało, że fundusze pożyczkowe i poręczeniowe podjęły również działania ułatwiające uzyskanie przez MŚP dostępu do finansowania. Wśród tych działań należy przede wszystkim wyróżnić:

- uwzględnienie specyfiki MŚP przy ustalaniu warunków otrzymania produktu (100\% funduszy pożyczkowych i $67 \%$ funduszy poręczeniowych),

- udzielaniu pomocy MŚP przy spełnianiu wymogów uzyskania produktu finansowego (100\% funduszy pożyczkowych i 50\% funduszy poręczeniowych),

- uproszczenia przy określaniu sytuacji finansowej MŚP (80\% funduszy pożyczkowych i $50 \%$ funduszy poręczeniowych),

- uproszczenie sposobu badania zdolności do uzyskania produktu (60\% funduszy pożyczkowych i $67 \%$ funduszy poręczeniowych),

- obniżenie wysokości odsetek $(60 \%$ funduszy pożyczkowych i $50 \%$ funduszy poręczeniowych),

- uelastycznieniu warunków spłat (40\% funduszy pożyczkowych i $67 \%$ funduszy poręczeniowych),

- stosowaniu prostszych form zabezpieczeń (40\% funduszy pożyczkowych i $83 \%$ funduszy poręczeniowych),

- rozszerzenie oferty (40\% funduszy pożyczkowych i 50\% funduszy poręczeniowych).

Z punktu widzenia funduszy pożyczkowych i poręczeniowych najważniejszym ograniczeniem we współpracy z MŚP jest brak pełnej dokumentacji finansowej (100\% funduszy pożyczkowych i 50\% funduszy poręczeniowych) oraz brak wystarczającego majątku do zabezpieczenia ( $80 \%$ funduszy pożyczkowych i $83 \%$ funduszy poręczeniowych). Wśród innych ograniczeń wymieniono brak wiedzy na temat specyfiki produktu i konieczność doradztwa (40\% funduszy pożyczkowych i 50\% funduszy poręczeniowych) oraz negatywne nastawienie MŚP do kapitału obcego (20\% funduszy pożyczkowych i 50\% funduszy poręczeniowych).

Podobnie najczęstsze przyczyny nieotrzymania przez MŚP wsparcia ze strony instytucji finansowych wiążą się z ich sytuacją finansową. Są to następujące czynniki:

- niemożliwość zapewnienia zabezpieczenia spłaty (100\% funduszy pożyczkowych i 67\% funduszy poręczeniowych),

- brak zdolności do spłaty (100\% funduszy pożyczkowych i 33\% funduszy poręczeniowych),

- sytuacja finansowa w branży MŚP (80\% funduszy pożyczkowych i $83 \%$ funduszy poręczeniowych),

- groźba upadłości oraz słabo udokumentowana sytuacja finansowa MŚP (80\% funduszy pożyczkowych i 50\% funduszy poręczeniowych),

- brak perspektyw rozwoju MŚP (60\% funduszy pożyczkowych i $33 \%$ funduszy poręczeniowych),

- sytuacja makroekonomiczna w Polsce (20\% funduszy pożyczkowych i 50\% funduszy poręczeniowych). 
Działalność funduszy współpracujących z MŚP charakteryzuje się rozwiązaniami i instrumentami ukierunkowanymi na ten sektor gospodarki, uwzględniającymi jego specyfikę i przyczyniającymi się do poprawy ich pozycji konkurencyjnej dzięki oferowaniu preferencyjnych warunków, co polega głównie na obniżaniu kosztów oferowanych produktów, upraszczaniu ich konstrukcji, niższych wymogach, kompleksowości obsługi. Działania te mają na celu zwiększenie dostępności i ułatwienie MŚP korzystania z oferty. Badane fundusze zwracają jednocześnie uwagę na utrudnienia we współpracy z sektorem MŚP. Do najistotniejszych z nich zaliczono: brak pełnej dokumentacji finansowej, słabą sytuację finansową, w tym brak wystarczającego majątku do zabezpieczenia oraz negatywne nastawienie do kapitałów obcych. Te czynniki przyczyniają się również w znacznym stopniu do nieudzielenia wsparcia MŚP przez badane fundusze.

Fundusze pożyczkowe i poręczeniowe wskazały również w badaniu mocne i słabe strony MŚP. Do mocnych stron najczęściej należą - zarządzanie przedsiębiorstwem przez właściciela i prosta struktura organizacyjna (80\% funduszy pożyczkowych i 67\% funduszy poręczeniowych) a także elastyczność działania oraz możliwość szybkiej zmiany profilu działalności $(60 \%$ funduszy pożyczkowych i $67 \%$ funduszy poręczeniowych). Najczęściej wymieniane przez fundusze słabe strony MŚP, to brak pełnej dokumentacji finansowej (100\% funduszy pożyczkowych i 50\% funduszy poręczeniowych), niewielki majątek służący zabezpieczeniu ( $80 \%$ funduszy pożyczkowych i $83 \%$ funduszy poręczeniowych) oraz niebezpieczeństwo bankructwa ( $60 \%$ funduszy pożyczkowych i $67 \%$ funduszy poręczeniowych).

Fundusze wskazały również najtrudniejsze do spełnienia wymogi stawiane MŚP. Za najważniejsze z nich uznano zapewnienie zabezpieczenia spłaty (100\% funduszy pożyczkowych i 50\% funduszy poręczeniowych), odpowiednie udokumentowanie sytuacji finansowej (80\% funduszy pożyczkowych i 83\% funduszy poręczeniowych) oraz przygotowanie odpowiedniego biznesplanu (60\% funduszy pożyczkowych i 50\% funduszy poręczeniowych).

Wskazane mocne strony MŚP to charakterystyczne cechy MŚP. Z kolei słabe strony MŚP prowadzą do trudności w spełnieniu warunków uzyskania wsparcia.

W odniesieniu do postawy MŚP wobec funduszy warto zwrócić uwagę na wyniki badań H. Waniak-Michalak, w której badaniach ankietowani przedsiębiorcy, niekorzystający z usług funduszy poręczeniowych, przyznali, że nie mają żadnych informacji na temat funduszy poręczeniowych (województwo mazowieckie - 57,1\%, województwo podkarpackie - 37,5\%, województwo łódzkie - 30,2\%) lub również mieli trudności z uzyskaniem takich informacji (województwo mazowieckie - 28,6\%, województwo podkarpackie - 18,8\%, województwo łódzkie - 28,1\%) (Waniak-Michalak, 2007, s. 201).

Podobnie ankietowani przedsiębiorcy w badaniu H. Waniak-Michalak, niekorzystający z usług funduszy pożyczkowych, wśród przyczyn takiej postawy wskazali na nieświadomość istnienia takich instytucji (województwo mazowieckie - 84,2\%, województwo podkarpackie $28,6 \%$, województwo łódzkie - 22,9\%), niską atrakcyjność oferty (województwo mazowieckie $15,8 \%$, województwo podkarpackie - 28,5\%, województwo łódzkie - 27,1\%) oraz na problemy z uzyskaniem kompletnych informacji na temat ofert funduszu (województwo podkarpackie 20,6\%, województwo łódzkie - 23,4\%) (Waniak-Michalak, 2007, s. 205). 
Przedstawione badanie jednoznacznie wskazuje, że MŚP nie mają dostatecznej wiedzy na temat funduszy. Oznacza to też, że są bierne w zakresie uzyskania takich informacji.

\section{Podsumowanie}

Poręczenia i pożyczki z sektora pozabankowego wykorzystywane są w niewielkiej skali przez ogół MŚP. Mają one natomiast duże znaczenie dla mikro- oraz małych przedsiębiorstw, które mają problemy z finansowaniem działalności kredytem czy leasingiem. Takie podmioty korzystają z usług funduszy pożyczkowych i poręczeniowych, a wśród efektów tej współpracy należy odnotować wzrost poziomu ich rozwoju. MŚP podkreślają rolę poręczeń i pożyczek we wzmacnianiu pozycji rynkowej.

Ofertę funduszy poręczeniowych i pożyczkowych należy uznać za dostosowaną do potrzeb i specyfiki MŚP. Wskazują na to wyniki badań MŚP i działania podejmowane przez fundusze. Biorąc pod uwagę, że z usług funduszy korzystają głównie mikro- i małe przedsiębiorstwa, bardzo ważną rolą jest pomoc oferowana przez fundusze odnośnie do wypełniania wymaganych dokumentów, w szczególności biznesplanu oraz wniosków poręczeniowych czy pożyczkowych. Wysokość poręczeń i pożyczek, okres umowy, wysokość oprocentowania, sposoby zabezpieczeń wychodzą naprzeciw małym podmiotom.

Negatywnie należy ocenić przepływ informacji pomiędzy obiema grupami podmiotów. MŚP jako jedno z głównych utrudnień przy korzystaniu z tych źródeł finansowania wskazują na brak informacji o istnieniu tych funduszy. Jednocześnie nie podejmują działań, aby te informacje uzyskać, co wynika z ich biernej postawy.

\section{Literatura}

Adamek, J. (2006). Instytucje poręczeń i gwarancji kredytowych dla małych i średnich przedsiębiorstw-doświadczenia polskie i zagraniczne. Wrocław: Wydawnictwo Akademii Ekonomicznej we Wrocławiu.

Alińska, A. (2008). Instytucje mikrofinansowe w lokalnym rozwoju społeczno-gospodarczym. Warszawa: SGH.

Bartkowiak, B. (2009). Fundusze pożyczkowe i poręczeniowe $w$ finansowaniu matych $i$ średnich przedsiębiorstw w Polsce. Warszawa: CeDeWu.

Bartkowiak, B., Flejterski, S., Pluskota, P. (2006). Fundusze i usługi pożyczkowe dla mikro, matych i średnich przedsiębiorstw. Warszawa: Difin.

Bernat, A. (2015). Luka finansowa w sektorze mikro, małych i średnich przedsiębiorstw na przykładzie województwa świętokrzyskiego. Warszawa: CeDeWu.

Bławat, F. (red.) (2004). Przetrwanie i rozwój małych i średnich przedsiębiorstw. Gdańsk: Scientific Publishing Group.

Fundusze pożyczkowe w Polsce za lata 2004-2009 (2005-2009). Szczecin: Polskie Stowarzyszenie Funduszy Pożyczkowych.

Janc, A., Waliszewski, K. (red.) (2014). Fundusze poręczeniowe i pożyczkowe w finansowym wspieraniu sektora mikro-, matych i średnich przedsiębiorstw w Polsce. Warszawa: CeDeWu.

Kubiak, J. (2005). Hierarchia źródel krótkoterminowego finansowania przedsiębiorstw. Poznań: Wydawnictwo Akademii Ekonomicznej w Poznaniu.

Łuczka, T. (2001). Kapitat obcy w matym i średnim przedsiębiorstwie. Warszawa-Poznań: Wydawnictwo Naukowe PWN.

Łuczka, T. (2013). Makro- i makroekonomiczne determinanty struktury kapitału $w$ matych i średnich przedsiębiorstwach. Poznań: Wydawnictwo Politechniki Poznańskiej.

Mikołajczyk, B. (2007). Infrastruktura finansowa MSP w krajach Unii Europejskiej. Warszawa: Difin. 
Nogalski, B., Karpacz, J., Wójcik-Karpacz, A. (2004). Funkcjonowanie i rozwój małych i średnich przedsiębiorstw. Bydgoszcz: AJG.

Poznańska, K. (1998). Uwarunkowania innowacji w małych i średnich przedsiębiorstwach. Warszawa: Dom Wydawniczy ABC.

Raporty o stanie funduszy poręczeń kredytowych w Polsce za lata 2001-2015 (2002-2016). Warszawa: Krajowe Stowarzyszenie Funduszy Poręczeniowych.

Rynek funduszy pożyczkowych w Polsce. Raport 2011-2015 (2012-2016). Warszawa: Polski Związek Funduszy Pożyczkowych.

Stan i perspektywy rozwoju funduszy pożyczkowych w Polsce wedtug stanu na 31.12.2010 r. (2011). Warszawa: Polski Związek Funduszy Pożyczkowych.

Waniak-Michalak, H. (2007). Pozabankowe źródła finansowania małych i średnich przedsiębiorstw. Kraków: Wolters Kluwer.

\section{Cytowanie}

Wolański, R. (2017). Fundusze pożyczkowe i poręczeniowe a małe i średnie przedsiębiorstwa - wzajemne interakcje. Współczesne Finanse. Teoria i Praktyka, 1 (2), 53-66. DOI: 10.18276/wf.2017.1-06. 